\title{
1. Introduction: for a European strategy at the turn of the century
}

Maria João Rodrigues

At the turn of the century, we must think in the long term. With this endeavour, the Presidency of the European Union organised a special interaction between the scientific and the political agenda. The purpose of this introduction is to reveal how this cross fertilisation was developed, leading to a new European strategy which aims to build a knowledge-based economy with more competitiveness and social cohesion. The main political dilemmas, the main theoretical issues, the new proposals and, finally, the political outcomes will be presented, providing a preliminary framework to highlight the following chapters.

\section{EUROPEAN DILEMMAS}

\subsection{What scenarios for Europe?}

Europe is facing a crucial period in its history. All the main issues of European civilisation are at stake and very contrasting scenarios are possible as shown in a wide range of literature (Delors, 1992; Wallace, 1990; Jacquemin and Wright, 1993; McRae, 1994; Bressard, 1997; Telò, 1998 and Fitoussi, 1999).

There is a bifurcation in each of the main factors shaping the European scenarios:

- In the international order, will we have a lasting American leadership or a more multipolar structure?

- In enlargement, will we have a slower or a faster pace?

- In the institutional reform, will we have a more confederal or a more federal evolution?

- In the creation of a single currency, will we have more or less credibility in the financial markets? 
- In the specialisation pattern, will we have more or less polarisation between high-skilled and low-skilled European regions?

- In macroeconomic policy, will the emphasis of the fine tuning be on inflation or on unemployment?

- In structural policies, will we have less or more effectiveness in economic redeployment?

- In combating the different risks of social exclusion, will we have less or more effective policies?

The most likely combinations of these alternatives can lead us to some very different scenarios:

- In the scenario 'Slow integration', Europe retards both enlargement and deepening, faces difficulties in affirming euro, cannot avoid the rise of unemployment and social exclusion and loses influence in the international game.

- In the scenario 'Enlargement as the priority', Europe speeds up enlargement and reaches more credibility with euro, but faces some difficulties in regional development, employment and social exclusion.

- In the scenario 'Enlargement and deepening', Europe also has success in enlargement and in the single currency, achieving it with more economic and social cohesion associated with some kind of political deepening and increasing international influence.

Other combinations and other scenarios are of course possible and this makes the European path a complex and an uncertain one.

The focus of this book will be on the economic and social development of the European Union, whilst bearing in mind this more general framework.

\subsection{A new paradigm creating a new context}

Europe is at the crossroads in a changing landscape. A completely new environment is being created by globalisation, technological change and an ageing population with its impact on the welfare state. With globalisation, nations are competing to attract investment, which, on the one hand, depends increasingly on the general conditions supporting business competitiveness. On the other hand, business competitiveness depends increasingly on the capacity to answer just in time to the specific needs of the customer. This involves managing a greater amount of knowledge with the intensive use of information technologies.

Knowledge is becoming the main source of wealth of nations, businesses 
and people, but it can also become the main source of inequalities among them. A new paradigm is emerging creating knowledge-based economies and societies. This is the broader significance we should give to the recent terminology about the 'new economy'.

Knowledge has always been an ingredient of human societies, but what is radically new is the speed of its accumulation and diffusion, due to information and telecommunication technologies. Working conditions and living conditions are being redefined. Markets and institutions are being redesigned by new rules based on the new possibilities of exchanging information. Internet is becoming the main infrastructure of this new paradigm.

Europe is somehow lagging behind in this transition and can learn a lot from the United States. But the point is not to imitate the United States, but rather to define the European way to the knowledge economy.

The challenges embodied in the European scenarios must be reexamined in the light of this emerging paradigm.

\subsection{Dilemmas and possibilities}

Some of these challenges concern competitiveness on the one hand and social cohesion on the other. Here we have a crucial dilemma. A realistic assessment might conclude that it is not possible to keep up with the socalled European social model, as this is now, in the new conditions created by globalisation and technological change, aggravated by ageing populations. Hence, a defensive answer to this prospect might consist of downgrading this European social model in order to increase competitiveness. A more affirmative answer, and also a more complex one is threefold: to build new competitive factors, to renew the European social model and to regulate globalisation.

Regulating globalisation depends on the ongoing reform of the United Nations and Bretton Woods institutions, namely the role of the International Monetary Fund (IMF) in financial markets, and on the next round of the World Trade Organisation (WTO) in order to foster multilateral trade. Better coordination of the foreign policies of European countries can also play a relevant role in this framework.

When building new competitive factors, a range of possibilities opened up by the knowledge-based economy should be explored in order to modernise companies, public services, schools, transports, cities and all the surrounding environment.

Renewing the European social model should create the conditions to help people move from jobs with no future to jobs with a future. This involves active employment policies, education and training, collective bargaining with a greater focus on change and more active social policies 
ensuring a safety network. This also involves making a special effort to prevent the digital divide, the new forms of social exclusion arising from the information society.

\subsection{Two central questions for Europe}

Two central question seem to emerge for Europe: How is it possible to speed up the transition towards a knowledge-based economy with more jobs and more social cohesion? How is it possible to make Europe a more competitive and dynamic economy, able to create more and better jobs and greater social cohesion?

These were exactly the central questions posed to Europeans leaders at the beginning of the century, the right moment to think in the long term.

As a background to their decision making, they were given a broad picture on the emerging knowledge-based economy.

\section{THE EMERGENCE OF THE KNOWLEDGE- BASED ECONOMY AS A GREAT TRANSFORMATION}

\subsection{The nature of the knowledge-based economy}

The knowledge-based economy is more than the so-called new economy. The fashionable term 'new economy' is sometimes limited to software and multimedia business, supported by active financial markets. But this is the tip of the iceberg. A much wider change is going on which encompasses all sectors of activity, from services, to manufacturing and even agriculture under the pervasive effect of information technologies and telecommunications (Cairncross, 1997; Thurow, 1999). A deluge of technological innovations is invading all these sectors and transforming our lives, from computers to computer-aided manufacturing, and from mobiles phones to digital TV, but even the other usual concept of 'information society' is limited to capturing the in-depth nature of the ongoing change.

As a matter of fact, the ongoing change is not only technological but also institutional, and it concerns something more than information, namely knowledge. We are living through a great transformation (with the meaning given by Polanyi [1944], 1983) which concerns the very social processes of knowledge production, diffusion and utilisation. Knowledge accumulation was speeded up in the past by major inventions, such as writing and printing. Communication between different communities was made more independent of their co-existence at the same time and in the same space. 
The current technological revolution is making human communication even more independent of time and space constraints, speeding up knowledge accumulation. The available knowledge at the cultural or scientific level is transformed in new contents and widely spread by increasingly powerful combinations of software and hardware. The knowledge intensity of products and services is also increasing, as can be seen in transport, health, education or entertainment. Knowledge is becoming the main raw material in many manufacturing companies. All social institutions work in a different way and even markets become more knowledge intensive, as displayed by financial markets or e-commerce.

A virtual reality is being built, the so-called cyberspace, whose main rules and architecture are still being defined, but which is already having powerful interactions with the existing world (e.g., Lévy, 1997). The organisation of the cyberspace is re-organising the existing world, shaping its economic, financial, political and cultural exchanges. Cognitive capacities, connectivity and cultural identity become the key instruments for survival in the new world. Internet and its social use is the most striking outcome of all this great transformation.

\subsection{Economic and social implications of the knowledge-based economy}

Knowledge is becoming the main source of wealth and power, but also of difference, between nations, regions, companies and people (Castells, 1996). Innovation based on a specific knowledge is the main competitive advantage. Competitiveness means to answer just in time to the personal needs of the customer, which requires a very sophisticated knowledge management. Mass customisation is succeeding to fordist standardised mass production (Tapscott, 1995). The foremost companies focus on the most value-added productions, build trade marks and launch wider operations of outsourcing and delocalisation. Network companies are spreading in all sectors and nations, reorganising the international division of labour. With e-commerce, businesses trade directly with businesses and the company dimension can become more irrelevant when taking advantage of globalisation. But soon the old intermediators are replaced by new intermediators capable of reorganising the market places in the cyberspace.

Knowledge management becomes a key component of corporate strategic management, activating the relationship between marketing, research and production. Corporate organisation is reshaped to build a learning organisation. New types of workers emerge, knowledge workers who have been categorised in different ways (Reich, 1991). Castells (1996) identifies new profiles, such as captains, innovators and connectors. Human resources 
management focus with increasing sophistication on the production of new competences as a source of competitiveness (e.g., Le Boterf, 1998). In the meantime, new risks of social exclusion, of a digital divide, emerge involving all the workers who cannot keep up with this pace of change.

Labour markets tend to new forms of segmentation between workers with voluntary mobility based on up-dated skills and workers who run the risk of involuntary mobility due to out-dated skills. The institutional framework of labour markets is being shaped in order to recombine employability and adaptability with basic conditions of security and citizenship (e.g., Esping-Andersen, 1999; Fitoussi and Rosanvallon, 1996). Labour market services are more focused on active employment policies; social protection systems on activating social policies; industrial relations on negotiating new trade-offs between flexibility and security. Finally, education and training systems are facing the challenge of building a learning society as a pre-condition to having a knowledge-based society and not only a knowledge-based economy (e.g., Lindley (with Nadel), 1998). To sum up, institutional innovations are emerging and new social rules are being invented.

How can we highlight our possible paths in this great transformation? In order to foresee and to discuss the possible scenarios, we must come back to some foundations underpinning this analysis of the emerging knowledge-based economy.

\section{THE INTELLECTUAL HORIZON AT THE TURN OF THE CENTURY}

Thinking in the long term at the turn of the century requires a prospective effort, building on our intellectual legacy. Hence, some major breakthroughs of the past century should be underlined, namely in the philosophy of knowledge, the philosophy of science and the philosophy of politics, because they are shaping our intellectual horizon.

\subsection{Philosophy of knowledge: theory shaping empirical evidence}

The approach about the relationship between theory and empirical evidence is a key issue for the development of science. The central controversy in the philosophy of science between rationalism and empiricism yielded important outcomes throughout the twentieth century. Overcoming the established tradition of the experimental method giving birth to hypotheses, the Vienna school stressed the preliminary role of theory by defining the hypothetico-deductive method. Moreover, the role of empirical evi- 
dence was more accurately defined by Popper with the concept of the falsifiability of a theory as opposed to the illusionary search of the verifiability of a given theory.

The role of theory in the construction of facts was highlighted in many different ways throughout the century:

- by Heisenberg's principle of indetermination;

- by Kuhn's concept of scientific revolutions based on new paradigms;

- by the identification of epistemological obstacles, such as teoricism and empiricism undertaken by Bachelard;

- by the theoretical developments on the role of language and of language games by Wittgenstein;

- by Habermas' theory on communicational action [1981] (1987);

- by the new insights coming from semiotics and cognitive sciences, with the pioneering work of Simon in economics and, very recently, from neurobiology, with Damásio (1995).

More recently, the transition of the century was signalled with a major transformation of the processes of knowledge accumulation and diffusion, hugely accelerated by information and telecommunication technologies. As the new cyberspace is being organised, it is becoming even more clear that there is no linear accumulation of knowledge. Instead there is creation and destruction of knowledge, conflicts for influence and emerging hegemonic poles with power to structure knowledge.

\subsection{Philosophy of science: complexity and multidimensionality}

Shifts in the philosophy of knowledge led to shifts in the philosophy of science. Cubist painting was perhaps the best pre-intuition of what was about to come. The object we see depends on the perspective. The complexity and the multidimensionality of the scientific object was also richly highlighted throughout the century, namely:

- in physics, by Einstein's theory of relativity;

- in biology, with the introduction of the concepts of evolution, the genetic code, irreversibility, entropy and regulation, as shown by Prigogine and Sengers;

- in human and social sciences with the introduction of the role of values, representations, social norms, institutions, as well as individual freedom in understanding, choosing and behaving, as recently reelaborated by Morin and Naïr (1997), Sen (1999), Bartoli (1991), Bourdieu (1979) or Giddens (1984). 
The scientific paradigm based on Newtonian physics, a reversible mechanism without time dimension, still survives in different sciences, including economics. Nevertheless it seems increasingly a simplification with too many limits, only useful in a small range of cases (e.g., Parrochia, 1997). Yet, science must be able to simplify complexity in order to explain, predict and transform. A new generation of models and mathematical tools is now being created, involving artificial intelligence in order to cope with complexity and multidimensionality.

One of the most outstanding implications of this new paradigm regards history and, more precisely, the philosophy of history. All social facts are embedded in history but there is neither a historicism, a pre-defined finality of history as stated by Marxist theory, nor an end of history as claimed by Fukuyama (1992). There are some strong trends with determination power, but there is also a degree of uncertainty and of influence coming from human action. This kind of approach can overcome the arguments raised by the post-modernist movement, very fashionable at the end of the last century.

Hence it is possible to speak not about a new historical stage but about a new historical situation emerging at the dawn of the century. The world order is being reshaped again, after a century of strong convulsions.

The twentieth century closes a long period in Europe marked by nationstates trying to create their own empire, with a final clash in the Second World War. But it is also a century marked by the experiments of the socialist revolution and subsequent developments of the Cold War, intertwined with decolonisation and the settlement of world-level organisations. Finally, the implosion of the Soviet Union and an enhanced hegemony of the United States co-exist with a faster diffusion of democracies and the emergence of regional blocs aiming at economic or even political integration, with a leading experience in Europe.

\subsection{Political philosophy: globalisation, social justice and governance}

The multiple implications of globalisation have became apparent more recently, not only in trade, industry and financial markets, but also in politics, culture and media (e.g., Held et al., 1999). Global actors coming from civil society are the final demonstration. Heavy imbalances seem to emerge at social and environmental levels, calling for new forms of regulation at the world level (e.g., United Nations, 2000; Bartoli, 1999).

However, globalisation is also opening up important opportunities for growth and development, and radical technological innovations, like those in information technologies and genetic engineering, are creating powerful tools to answer these imbalances. As shown by Kuhn (1970), a new research programme usually arises from the confluence between new problems and 
new approaches. One typical research programme for the twenty-first century could be to focus on a central issue: how to use information and genetic technologies to reduce the social and the environmental imbalances at world level?

Nevertheless, the implementation of the possible solutions pointed out by this research programme would be mainly a political problem, requiring political choices.

In the field of political philosophy, the past century also leaves a legacy of remarkable redeployment. After a period of strong ideological cleavages, there seems now to be a greater convergence in the values of liberty, formal legal equality and, more recently, even in individual initiative and responsibility (e.g., Eatwell and Wright, 1993 and Giddens, 1998). Political controversy seems now to be more focused on defining social justice (see Rawls [1972], 1989) and setting the level and the forms of solidarity required to overcome the social imbalances.

New approaches are also being proposed in order to redefine political action and the relevant political structures. Bearing in mind all this new intellectual horizon highlighted above, one could ask: how to define a method of political action able to deal with complexity and uncertainty, to build on available knowledge, to create a larger consensus in civil society and to overcome the main imbalances? As a matter of fact, this is a central issue for an already ongoing action-research programme on governance. Governance is not only a matter of government but of many others actors, relevant to political action and regulation (e.g., Kooiman, 1993).

Taking into account the above-mentioned imbalances at the world level, some key problems for the present century will therefore be: how can we build a multilevel system of governance combining the world, the regional, the national and the sub-national level? How can this multilevel system of governance promote openness, diversity and cohesion at the world level?

\subsection{Europe at the crossroads}

Europe is at the crossroads of all these new issues of philosophy of knowledge, science and politics. Many reasons can be pointed out to explain this:

- first of all, because Europe was the first source of many of these theoretical and practical issues;

- because Europe carries a special responsibility in the new stage of knowledge production and diffusion created by cyberspace: what is at stake is to safeguard critical spirit, theoretical imagination, cultural and linguistic diversity. Multidimensionality and multiculturalism should be fostered, not impoverished. 
- because European countries have lost the illusions of rebuilding the empire and have engaged themselves in an ambitious process of cooperation and integration;

- because European countries are exploring a new path for governance based on a multilevel system encompassing local, national, regional and even world levels;

- finally, because European countries, due to their history, provide a wide range of sensitivities and knowledge about the problems of third countries.

From these different points of view, Europe can be considered a vital laboratory in the search for new solutions to cope with the new issues identified above.

\section{NEW INSIGHTS IN SOCIAL SCIENCES}

\subsection{Forecasting exercises and social theory}

Keeping this impressionistic picture of our legacy as a background, let us now turn to the future. But some theoretical and methodological considerations should be presented before identifying some key questions for the definition of a European strategy.

Prospective exercises and scenarios building are today a burgeoning discipline, widely accepted by both academic and political communities and by society at large. They are a device to cope with complexity and uncertainty and to support strategic choices at different levels. After the pioneering works of Forrester, diversified exercises are having an impact on policy making, such as the reports produced by OECD Futures Programme (2000).

All the methodological sophistication can be found in books, such as those of Kees Van Der Heijden (1996) and of Michel Godet (1991). Different stages must be gone through in order to build scenarios: identifying the key variables and analysing their relationships; examining the strategies of the different relevant actors regarding these structural relationships; exploring the possible scenarios; reducing uncertainty by identifying those scenarios which are most probable and those which could be more desirable; finally, drawing some conclusions for strategic decision making and for policy making. Building scenarios has also proved to be a stimulating learning process for those involved in the exercise.

Nevertheless ongoing experience has also shown that the forecasting and strategic capacity of these methodological instruments depend on the 
explanatory strength of the theoretical framework previously adopted, given that it determines the choice of the relevant variables, relationships and actors. Empirical research is also very important afterwards in order to estimate the probability of each scenario.

The theoretical framework adopted in whatever social science, in order to build scenarios and make strategic choices, is based on assumptions of fundamental social theory, even if they are not explicit. As shown by Turner ([1974], 1991), the different currents we find in the history of social theory can be classified according to two main criteria: the level of theorisation and the drive for change. The level of theorisation can be either macro or micro and the drive for change can either be mainly conflict and imbalances or cooperation, equilibrium and homeostasis.

Hence, the theories which focus on macro-theorisation are divided between those which emphasise conflict, such as the theories of Marx, Weber, Habermas or Dahrendorf, and those which emphasise equilibrium, such as the theories of Spencer, Durkheim, Parsons or Luhmann.

On the other hand, the theories which focuss on micro-theorisation range from exchange and rational choice theories (Mauss, Hechter) to interactionism (Mead, Goffman) which is more open to different representations of the reality and different rationalities according to the actors.

Some theories have been built more recently to overcome these opposing positions, in order to embody both macro and micro approaches and both conflict and cooperation as drivers for change. The traditional controversy between holism and individualism are explicitly overcome by the theories developed by Giddens (1984), Bourdieu (1979) or Burns and Flan (1987). There is a permanent interaction between structure and actors and not only a one-way relationship.

Burns' (1987) approach is particularly interesting for economics, if we accept that market dynamics depend not only on prices but also on social rules. Burns studies the system of social rules which structure and regulate social transactions and organisations. He also studies the very processes of production, interpretation and implementation of these social rules, involving learning, negotiation, conflict and the exercise of power. A stimulating theoretical framework is provided to analyse bottlenecks, innovations, structural change, strategic action and reform, either at the macro or micro level.

How far is economic thought absorbing these new insights coming from social theory?

\subsection{Economic dynamics and social context}

A crucial dilemma seems to have marked economic thought over the past century. Should the social and historical context be taken into account in 
order to analyse economic dynamics or should it be virtually sacrified in order to enable modelisation and more precise explanation and forecasting? At the turn of the century, serious attempts are being made in order to overcome this dilemma.

The influence of the social and historical context had explicitly been analysed by the institutional school with Veblen, or by the Austrian school with Schumpeter, but it was neglected in the major developments in the microeconomic foundations undertaken by Walras and Marshall. It was taken into account in Keynes' major breakthrough, aimed at building macroeconomic tools to analyse short-term fluctuations of growth and employment creation. But Keynesian theory faced some difficulties adapting itself to the new context of open economies, increasing globalisation, the role of rational expectations and the vanishing of monetary illusion. The criticisms coming from monetarists and the new classics explored these weaknesses of Keynesian theory, but in a field where the historical and social dimensions were deliberately excluded in order to build alternative theories with the main concern, not of realistic assumptions, but rather of operational instrumentality and falsifiability.

The importance of controlling inflation is much more consensual today even among Keynesian economists, but the different sensitivities between Keynesians and monetarists continue to have some relevance. These differences concern namely the impact of monetary or fiscal policy and the possibility of stimulating demand in order to foster growth and employment. Nowadays, however, this only requires a fine-tuning of the policy mix in the framework of sustainable growth.

These controversies also had the merit of pointing out the need to go beyond the policy mix options in the short term and to focus on the very foundations of economic growth, in the long term. Following the models of Harrod-Domar, Solow and Cobb-Douglas, a new generation of models based on endogenous growth highlighted the role of investment in research and development (R\&D) and human capital in fostering growth and catching up (e.g., Romer, 1990, Silverberg and Soete, 1994). The same principle has been emphasised by neo-factorial and technological theories in international economics (e.g., Krugman and Obstfeld, 1994).

Reaching this frontier, economic theory seems to incorporate new dimensions of analysis, although it does not make them explicit. What is behind the investment in R\&D and human capital, the increasing mastering of a concrete technology and a given technological trajectory? As shown by the evolutionary theory (e.g., Dosi et al., 1988; Lundvall, 1992), we can find learning processes which occur in different institutional frameworks, with different rules and different actor games. Different social 
arrangements can underpin learning by doing, learning by using and learning by interacting.

Analysing long-and short-term dynamics by unveiling their institutional frameworks has been an area of convergence of more recent approaches, such as the evolutionary theory (Hodgson, 1993) and the regulation theory (Aglietta, 1976; Boyer and Saillard, 1995), which explains how the historical emergence of a new growth regime also depends on the renewal of social rules and institutional forms. These recent theoretical developments provide interesting tools with which to think about the role of structural policies and of institutional reforms in fostering growth and employment. More precisely, the emergence of a new growth regime based on knowledge seems to depend on institutional innovation, on the invention of new social rules.

Building on the legacy of the past century, a new theoretical paradigm also seems to emerge for social sciences based on the following principles:

- building a conceptual framework based on more realistic assumptions, able to take into account the diversity, complexity and multidimensionality of situations;

- going beyond the simplification of the homo economicus and taking into account different levels of information and different patterns of rationality;

- overcoming the limits of methodological individualism by accepting a permanent interaction between individuals and structures, institutions and social rules;

- admitting asymmetric relationships between actors which can involve either conflict or cooperation;

- taking not the equilibrium conditions but the evolution, the innovation and the learning conditions as the points of departure for analysis, even if the final purpose is also to explain equilibrium.

At the dawn of the century we are confronted with a crucial doubt: how far can a new theoretical paradigm enable us to cope with new economic and social paradigms?

Hence, preparing for the transition to a knowledge-based economy and society seems to be a difficult challenge both in theoretical and political terms. To cope with this challenge, cross-fertilisation between the scientific and the political agenda was put under way at the European level. 


\section{RESHAPING THE EUROPEAN AGENDA}

\subsection{Our main issues}

Despite a number of undeniable successes, Europe is lagging behind in this transition to an innovation- and knowledge-based economy. This delay is apparent in the production and dissemination of many information technologies, but also in the adaptation of social institutions and social relations to the new growth potential opened up by these technologies. While this failure to adapt to the new paradigm continues, there will be a shortfall in economic growth and an increased risk of unemployment and social exclusion.

In order to foster this growth potential, institutional reform should focus on innovation systems, R\&D systems, financial systems, education systems, labour market management and social protection systems.

Moreover, this institutional reform has not only a national but also a European dimension. National realities are very diversified in those various systems (Albert, 1991) but they face common problems of structural adjustment and they are influenced by a common framework based on a single market, a single currency, common competition and monetary policies, coordinated macroeconomic policies and some common standards at social and environmental levels.

This means that some level of European coordination is required in order to undertake these institutional reforms, while respecting national specificity. A multilevel governance system is needed based on the interaction at the European, the national and the sub-national levels.

All these issues led to a central question being analysed when preparing for the Presidency of the European Union: in order to strengthen its growth perspectives and to sustain its basic social model, Europe will have to build a new competitive platform based on innovation and knowledge. But there are risks in this transition. How can a knowledge-based economy be built with more and better jobs and more social cohesion?

Against this background, some more precise questions were identified to be addressed with intellectual autonomy by the different authors of this book, well known for their approaches and important contributions in these fields. In particular:

- by Luc Soete, the challenges and the potential for growth of a knowledge-based economy in a globalised world;

- by Gøsta Esping-Anderson, the new challenges for the welfare state resulting from an ageing population, globalisation and the emergence of a knowledge-based economy; 
- by Robert Lindley, the emerging trends in employment, the need for new skills and the new threats of social exclusion in the transition to a knowledge-based economy;

- by Robert Boyer, the institutional reforms required to implement a policy mix for growth, employment and social cohesion in the transition to a knowledge-based economy;

- by Bengt-Åke Lundvall, the role of international benchmarking as a policy learning tool;

- by Manuel Castells, the construction of the European identity against the background of these societal changes;

- by Mario Telò, the building of a multilevel governance with government required to undertake these reforms.

The main purpose was to identify which institutional innovations could change the way in which European societies are currently regulated, so as to pave the way for a new development trajectory, for a more desirable scenario among the possible ones. This required the in-depth organisation of interactions and a kind of cross-fertilisation between the scientific and the ongoing European political agenda. The outcome was supposed to be a review of the European agenda in the light of this new set of issues.

\subsection{The topics in discussion in the European agenda}

The Portuguese Presidency of the European Union at the beginning of 2000 endeavoured to make a contribution to the long-term decision to update the European strategy for growth, competitiveness and employment in the light of the new conditions and building on previous outstanding contributions (namely, European Commission, 1994). This strategy should comprise macroeconomic policies, economic reforms and structural policies, such as R\&D, innovation and enterprise policies, education policy, employment policy and social protection policy.

In the preparatory period of this Presidency, some main issues were being discussed at the European level based on a long list of documents.

Regarding macroeconomic policy:

- How to improve the policy mix for sustainable growth and employment in the framework defined by the Stability and Growth Pact?

- How can monetary policy contribute to growth if its main task, defined by the Treaties, is to control inflation?

- How far can automatic stabilisers of budgetary policy be used in order to sustain growth?

- What should the priorities of public investment be? 
- How far should tax policy go in coordination?

- How should wage developments be made compatible with inflation control and rising living standards?

- What should the role of the macroeconomic dialogue with social partners be in the framework of the Cologne process?

- How can the risks of social dumping be avoided?

- How can the effectiveness of the official document of Broad Economic Policy Guidelines (BEPG) be improved?

Regarding the coordination between macroeconomic policies:

- What should the economic coordination be between member states: setting common objectives, monitoring their implementation at the national level as already done? Or to go further aiming at an evaluation of the aggregate effects of the different national choices, or even at an implementation of common tools to deal with problems, such as asymmetric or global shocks?

Regarding economic reforms:

- Which should the priorities for economic reform be in the fields of liberalisation, privatisation, competition policy, public services modernisation, financial markets integration, venture capital development, support to small and medium-size economies (SMEs)?

- How should the effectiveness of the Cardiff process of economic reforms be improved?

Regarding employment policies:

- How should the high unemployment rate in Europe be reduced? Should it be possible to adopt a common target about the unemployment rate? How should an employment strategy based on the Luxembourg process be developed in order to foster more and better jobs?

- How should the four pillars of employability, enterpreneurship, adaptability and equal opportunities be combined in order to renew the European social model?

- How should social partners and other actors be involved in this strategy?

- How should corporate social responsibility be encouraged? 
- How should the increasing skill shortages be faced?

- How should lifelong learning be developed?

- What can the contribution of education policies be at the European level if they are only at a stage of cooperation?

Regarding social protection:

- What can a concerted strategy for modernising social protection be if these policies are at an even more preliminary stage of cooperation at the European level? Some priorities have been defined: making work pay and ensuring a stable income; enhancing the sustainability of pension systems; promoting social inclusion and providing a highquality health system. But how should these priorities be implemented?

- What can the future of the welfare state in Europe be?

Regarding governance:

- How can strategic leadership be enhanced for better coordination between economic, technological and social policies in Europe?

\subsection{A cluster of new political orientations}

A cluster of new political orientations began to emerge from all the interaction organised between the political and the scientific community in order to reshape the European agenda:

- defining a global strategy for a knowledge-based economy with social inclusion, with implications for the various economic and social policies;

- discussing not only the quantity but also the quality of public finances; giving a clear priority to public investments in R\&D, innovation, education and training; using tax policy to support innovative SMEs; enhancing public-private partnerships to launch ambitious info-structures;

- improving macroeconomic coordination with a more clear definition of the role of each actor and each level of decision making;

- focusing economic reform on enhancing the potential for growth and innovation;

- launching an ambitious plan for the information society facilitating access to the Internet, stimulating new contents, combating infoexclusion, focusing new citizen needs in education, health, transports, environment; 
- coordinating national policies in order to enhance European potential in R\&D;

- going beyond the traditional reforms of education and training systems and exploring new ways of building a learning society with opportunities for all;

- reforming the European social model by investing in people, activating the welfare state and enhancing the fight against social exclusion in its old and new forms, such as technological illiteracy;

- re-thinking the nature and the scope of the welfare state, considering not only guaranteed income, but also personal services, quality of work and living opportunities as basic components of social cohesion and social justice;

- enhancing the sustainability of pension systems by raising the employment rate which requires namely to foster jobs creation in services, to improve employability, to reconsider early retirements and to enhance equal opportunities;

- examining the interaction between the European and the national forms of regulation;

- analysing the sources of European identity and the role of a multilevel system of governance to build it;

- improving the role of social dialogue and other forms of partnership in order to manage change;

- introducing innovations in political method in order to improve coordination, monitoring, accountability and learning processes. In short, a more knowledge-based policy making.

The first outcome of this cross-fertilisation between the scientific and the political agendas was the Document from the Presidency presented in an annex under the title 'Employment, economic reforms and social cohesion - towards a Europe based on innovation and knowledge'. The main scientific inputs are the core of this book. This political and scientific starting point would be followed by dozens of documents prepared by the European Commission, the Council, all European governments, the European Parliament and the other European institutions, the social partners and many others actors at European and national levels.

The Lisbon European Council, held in March 2000, defined and put into practice the European strategy for the knowledge-based economy - now formally recognised as the 'Lisbon Strategy'. Its results began to be felt in various policy areas, namely the information society, in research, innovation, the internal market, in education, employment, social protection, social inclusion - even in macroeconomic policies.

There is a story behind all this that deserves to be told, so that we can 
understand the extent of this strategy and the new set of problems and of solutions for Europe.

\subsection{Tailoring and leading political change}

However, key ideas needed to lead to political decision taking and action. The entire Presidency was tailored to achieving this goal, throughout its two European Councils, fourteen Councils of Ministers, an International Hearing (1999), seven Ministerial Conferences, and several sessions of the European Parliament and a high-level Forum grouping the major stakeholders in Europe and the member states.

As the main objective was to define a global strategy, the key role had to be played by the European Council - in synergy with the initiatives of the European Commission. The meeting of the European Council had to be special and focused only on this objective. We had to hold it sufficiently early to provide guidance for the following Councils of Ministers and sufficiently late to allow for the strong effort in persuasion required to reach agreement. This action relied on a series of ambitious initiatives formally proposed by the Presidency, at its own risk, resulting in multiple contacts made with all community bodies and national governments. Ultimately it led to the prime minister's visit to all EU capitals. Public debate also made it possible to collect a widely diversified set of contributions from civil society, from all EU governments and from all community bodies.

Decisions made at the Lisbon European Council helped define the final shape of the high-level consensus and mobilisation obtained during this process, by establishing more precise objectives, calendars and methods and defining the mandates of all Councils of Ministers involved. This propeller enabled the last meeting of the European Council at Feira to produce a set of concrete results, which began to be translated at the national level and developed during the following Presidencies.

\subsection{The Lisbon Strategy}

A new strategic goal and an overall strategy was defined by Lisbon European Council in 2000. Quoting its own Conclusions:

'The Union has today set itself a new strategic goal for the next decade: to become the most competitive and dynamic knowledge-based economy in the world capable of sustainable economic growth with more and better jobs and greater social cohesion. Achieving this goal requires an overall strategy aimed at: 
- preparing the transition to a knowledge-based economy and society by better policies for the information society and R\&D, as well as by stepping up the process of structural reform for competitiveness and innovation and by completing the internal market;

- modernising the European social model, investing in people and combating social exclusion;

- sustaining the healthy economic outlook and favourable growth prospects by applying an appropriate macro-economic policy mix.'

Lisbon Strategy set the following main political orientations:

- a policy for the information society aimed at improving the citizens' standards of living, with concrete applications in the fields of education, public services, electronic commerce, health and urban management; a new impetus to spread information technologies in companies, namely e-commerce and knowledge-based management tools; an ambition to deploy advanced telecommunications networks and democratise the access to the Internet, on the one hand, and produce contents that add value to Europe's cultural and scientific heritage, on the other;

- an R\&D policy whereby the existing community programme and the national policies converge into a European area of research by networking R\&D programmes and institutions. A strong priority for innovation policies and the creation of a European patent;

- an enterprise policy going beyond the existing community programme, combining it with a coordination of national policies in order to create better conditions for entrepreneurship - namely administrative simplification, access to venture capital or manager training;

- economic reforms that target the creation of growth and innovation potential, improve financial markets to support new investments, and complete Europe's internal market by liberalising the basic sectors while respecting the public service inherent to the European model;

- macroeconomic policies which, in addition to keeping the existing macroeconomic stability, vitalise growth, employment and structural change, using budgetary and tax policies to foster education, training, research and innovation;

- a renewed European social model relying on three key drivers, i.e. making more investment in people, activating social policies and strengthening action against old and new forms of social exclusion;

- new priorities defined for national education policies, i.e. turning schools into open learning centres, providing support to each and 
every population group, using the Internet and multimedia; in addition, Europe should adopt a framework of new basic skills and create a European diploma to embattle computer illiteracy;

- active employment policies intensified with the aim of making lifelong training generally available and expanding employment in services (especially care services) as a significant source of job creation, improvement of the standards of living and promotion of equal opportunities for women and men. Raising Europe's employment rate was adopted as a key target in order to reduce the unemployment rate and to consolidate the sustainability of the social protection systems;

- an organised process of cooperation between the member states to modernise social protection, identifying reforms to answer common problems, such as matching pension systems with population ageing;

- national plans under preparation to take action against social exclusion in each and every dimension of the problem (including education, health, housing) and meeting the requirements of target groups specific to each national situation;

- improved social dialogue in managing change and setting up of various forms of partnership with civil society, including the dissemination of best practices of companies with higher social responsibility.

\subsection{Strategy and governance}

The actual implementation of any strategy requires a political engine, i.e. a governance centre at the European level with the power to coordinate policies and adapt them to each national context. The Lisbon decisions made this governance centre stronger, in three ways:

- firstly, the European Council will play a stronger role as coordinator, henceforth devoting its spring meeting to the monitoring of this strategy, based on a synthesis report presented by the European Commission;

- secondly, the broad economic policy guidelines will improve the synergy between macroeconomic policies, structural policies and employment policy;

- thirdly, the Union adopted an open method coordination, which will begin to be applied to all policy fields, stepping up the translation of European priorities into national policies.

This method combines European coherence and respect for national diversity. It defines the required European guidelines in each policy 
domain, subsequently identifying best practices and reference indicators and, finally, materialising in national plans consisting of concrete targets and measures fitting each country's case. Its purpose is to set up a vast process of innovation, learning and emulation between European countries, in which the European Commission may play a new role as catalyst. The method actually aims to speed up real convergence, now that nominal convergence is being achieved in order to prepare for the single currency.

The political construction of Europe is being based on different political methods in accordance with the problems to be solved. Various methods have been worked out which are placed somewhere between pure integration and straightforward cooperation. Hence:

- Monetary policy is a single policy within the euro zone.

- National budgetary policies are coordinated at the European level on the basis of strictly predefined criteria.

- Employment policies are coordinated at the European level on the basis of guidelines and certain indicators, allowing some room for adjustment at the national level.

- A process of cooperation is beginning with a view to the modernisation of social protection policies, with due regard for national differences.

Policies aimed at building the single market, such as monetary policy or competition policy, are, logically, based on a stricter method of coordination in relation to the principles to be observed. However, there are other policies which concentrate more on creating new skills and capacities for making use of this market and responding to structural changes. They involve learning more quickly and discovering appropriate solutions. Such policies have resulted in the formulation of a coordination method which is more open to national diversity.

\subsection{The open method of coordination}

The open method of coordination is based on different stages:

- defining guidelines for the Union combined with specific timetables for achieving the goals which they set in the short, medium and long terms;

- exchanging best practices and, where appropriate, establishing quantitative and qualitative indicators and benchmarks against the best in the world and tailored to the needs of different member states; 
- translating these European guidelines into national and regional policies by setting specific targets and adopting measures;

- periodic monitoring, evaluation and peer review organised as mutual learning processes.

The open method of coordination is a concrete way of developing modern governance using the principle of subsidiarity. This method can foster convergence in common interest and in some agreed common priorities while respecting national and regional diversities. It is an inclusive method for deepening European construction.

The purpose of the open method of coordination is not to define a general ranking of member states in each policy, but rather to organise a learning process at the European level in order to stimulate exchange and the emulation of best practices as well as to help member states improve their own national policies.

The open method of coordination is to be combined with the other available methods depending on the problem to be addressed. These methods can range from integration and harmonisation, to cooperation. The open method of coordination itself takes an intermediate position in this range of different methods. It is an instrument to be added to a more general set of instruments.

The European Commission can play a crucial role as a catalyst in the different stages of the open method of coordination namely by: presenting proposals on European guidelines, organising the exchange of best practices, presenting proposals on indicators, and supporting monitoring and peer review.

Monitoring and evaluation should be based on systemic approaches in the national context and should help to create a culture of strategic management and of learning by experience, involving all relevant partners.

The main source of inspiration for the open method of coordination is the Luxembourg process regarding European employment strategy. Following the Lisbon Summit conclusions, this method is now being implemented in different policy fields, namely, the information society, R\&D, enterprises, economic reforms, education and social inclusion. An empirical and flexible approach is being used in order to develop and to adapt this method to the specific features of each policy field.

Developing the knowledge-based economy with social cohesion and promoting real convergence in Europe, by matching the community drive with national policies - this will be the main test for the Lisbon Strategy over the coming years. This challenge involves various complex issues which will be developed in the following chapters. 


\section{REFERENCES}

Aglietta, Michel (1976), Régulation et crises du capitalisme, reprinted (1997), Paris: Odile Jacob.

Albert, Michel (1991), Capitalisme contre capitalisme, Paris: Seuil.

Artis, Michael J. and Norman Lee (eds) (1997), The Economics of the European Union - Policy and Analysis, Oxford: Oxford University Press.

Baldwin, Robert and Martin Cave (1999), Understanding Regulation, Oxford: Oxford University Press.

Bartoli, Henri (1991), L'économie multidimensionnelle, Paris: Economica.

Bartoli, Henri (1999), Repenser le Développement - En finir avec la pauvreté, Paris: UNESCO - Economica.

Blaug, Mark (1962), Economic theory in retrospect, reprinted in Cambridge: Cambridge University Press (1988).

Bourdieu, Pierre (1979), La distinction - Critique sociale du jugement de gout, Paris: Les Éditions de minuit.

Boyer, Robert (1986), La théorie de la régulation: une analyse critique, Paris: Editions La Découverte.

Boyer, Robert and Yves Saillard (1995), Théorie de la régulation - L'état des savoirs, Paris: Editions La Découverte.

Bressard, Albert (1997), Europe 2012, Globalisation et Cohésion sociale, Paris: Economica

Burns, Tom R. and Helena Flam (1987), The Shaping of Social Organisation Social Rule System Theory with Applications, London: Sage.

Cairncross, Frances (1997), The Death of Distance - How the Communications Revolution will Change our Lives, London: Orion Publishing Group.

Castells, Manuel (1996), The Information Age: Economy, Society and Culture The Rise of the Network Society, vol. I, reprinted 1999, Oxford: Blackwell Publishers.

Commissariat Général du Plan (Rapport du groupe présidé par Jean-Louis Quermonne) (1999), L'Union européenne en quête d'institutions légitimes et efficaces, Paris: La Documentation française.

Conseil d'Analyse Economique (1998), Coordination européenne des politiques économiques, Paris: La Documentation française.

Damásio, António R. (1995), O erro de Descartes - emoção, razão e cérebro humano, Lisbon: Publicações Europa-América.

Delors, Jacques (1992), Le nouveau concert européen, Paris: Odile Jacob.

Delors, Jacques (1994), L'unité d'un homme, Paris: Odile Jacob.

De Schoutheete, Philippe (1997), Une Europe pour tous, Paris: Odile Jacob.

Dosi, Giovanni, Christopher Freeman, Richard Nelson, Gerald Silverberg and Luc Soete (eds) (1988), Technical Change and Economic Theory, London: Pinter.

Eatwell, Roger and Anthony Wright (eds) (1993), Contemporary Political Ideologies, reprinted (1994), London: Pinter.

Edwards, Geoffrey and David Spence (eds) (1994), The European Commission, reprinted (1997), London: Catermill Publishing.

Esping-Andersen, Gøsta (ed.) (1996), Welfare States in Transition - National Adaptations in Global Economics, reprinted 1998, London: Sage.

Esping-Andersen, Gøsta (1999), Social Foundations of Postindustrial Economies, Oxford: Oxford University Press.

European Commission (1994), Growth, Competitiveness, Employment - The 
Challenges and Ways Forward into the 21st Century, Luxembourg: Office for Official Publications of the European Communities.

Fitoussi, Jean-Paul (1995), Le débat interdit - Monnaie, Europe, Pauvreté, Paris: Arléa.

Fitoussi, Jean-Paul and Pierre Rosanvallon (1996), Le nouvel âge des inégalités, Paris: Seuil.

Fitoussi, Jean-Paul (sous la direction de) (1999), Rapport sur l'Etat de l'Union européenne, Paris: Fayard and les Presses de Sciences Po.

Fondation Alphonse Weicker (1997), Europe 2012 - Globalisation et cohésion sociale: les scénarios luxembourgeois, Paris: Economica.

Fries, Fabrice (1995), Les grands débats européens, Paris: Seuil.

Fukuyama, Francis (1992), The End of History and the Last Man, New York: Free Press.

Gaspard, Michel (1997), Réinventer la croissance - Les chemins de l'emploi en Europe, Paris: Editions La Découverte \& Syros.

Giddens, Anthony (1984), The Constitution of Society, Cambridge: Polity Press.

Giddens, Anthony (1998), The Third Way - The Renewal of Social Democracy, reprinted (1999), London: Polity Press.

Godet, Michel (1991), De l'anticipation à l'action - Manuel de prospective et de stratégie, Paris: Dunod.

Godino, Roger (1997), Les sept pilliers de la réforme, Paris: Albin Michel.

Habermas, Jürgen (1981), Theorie des kommunikativen Handels, reprinted (1985), Frankfurt: Suhrkamp Verlag.

Habermas, Jürgen (1987), Théorie de l'agir communicationnel - Tome 2 Pour une critique de la raison fonctionnaliste, Paris: Fayard.

Hatem, Fabrice (1993), La Prospective - Pratiques et Méthodes, Paris: Economica.

Hayes-Renshaw, Fiona and Helen Wallace (1997), The Council of Ministers, London: Macmillan.

Held, David, Anthony McGrew, David Goldblatt and Jonathan Perraton (1999), Global Transformations - Politics, Economics and Culture, Stanford, CA: Stanford University Press.

Hix, Simon (1999), The Political System of the European Union, London: Macmillan.

Hodgson, Geoffrey M. (1993), Economics and Evolution - Bringing Life Back into Economics, Cambridge: Polity Press.

Jacquemin, Alexis and David Wright (eds) (1993), The European challenges post1992 - Shaping Factors, Shaping Actors, Aldershot: Edward Elgar.

Kelund, E., R. Boyer and R.F. Hébert (1990), A History of Economic Theory and Method, New York: McGraw-Hill.

Kooiman, Jan (ed.) (1993), Modern Governance - New Government - Society Interactions, London: Sage.

Krugman, Paul R. and Maurice Obstfeld (1994), International economics: Theory and Policy, New York: HarperCollins College Publishers.

Kuhn, Thomas (1970), The Structure of Scientific Revolutions, Chicago, CO: University of Chicago Press.

Lafay, Gérard (1997), L'Euro contre l'Europe? - Guide du citoyen face à la monnaie unique, Paris: Arléa.

Le Boterf, Guy (1998), L'Ingénierie des compétences, Paris, Éditions d'Organisation.

Lévy, Pierre (1997), Cyberculture, Paris: Editions Odile Jacob/Editions du Conseil de l'Europe. 
Lindley, Robert (with H. Nadel) (eds) (1998), Les Relations Sociales en Europe, Paris: L'Harmattan.

Lundvall, Bengt-Åke (ed.) (1992), National Systems of Innovation - Towards a Theory of Innovation and Interactive Learning, London: Pinter.

McRae, Hamish (1994), The World in 2020 - Power, Culture and Prosperity: A Vision of the Future, London: HarperCollins.

Morin, Edgar (1987), Penser l'Europe, Paris: Gallimard.

Morin, Edgar and Sami Naïr (1997), Une politique de civilisation, Paris: Arléa.

OECD (2000), The Creative Society of the 21st Century, Paris: OECD.

Olivi, Bino (1998), L'Europe difficile - Histoire politique de la Communauté européenne, Paris: Gallimard.

Parrochia, Daniel (1997), Sciences exactes et sciences de l'homme: les grandes étapes, Paris: Ellipses.

Polanyi, Karl (1944), The Great Transformation, reprinted (1980), Boston, CO: Beacon Press.

Polanyi, Karl (1944), La Grande Transformation aux origines politiques et économiques de notre temps, reprinted (1983), Paris: Gallimard.

Popper, Karl (1959), The Logic of Scientific Discovery, New York: Harper Torch Books.

Porter, Michael E. (1990), The Competitive Advantage of Nations, London and Basingstoke: Macmillan.

Portuguese Presidency of the European Union, (1999), International Hearing (Giuseppe Bertola, Olivier Blanchard, Robert Boyer, Albert Bressand, Vítor Constâncio, Gøsta Esping-Andersen, Stephen Fuller, Robert Lindley, BengtÅke Lundvall, Carlos Medeiros, Lucio Pench, Marino Regini, Maria João Rodrigues, Michael Shuman, Luc Soete, Mario Telò, Göran Therborn, Jürgen Von Hagen).

Prigogine, Ilya and Isabelle Stengers (1979, 1986), La nouvelle alliance, Paris: Gallimard.

Prodi, Romano (1999), Un'idea dell'Europa - Il valore Europa per modernizzare l'Italia, Bologna: Società Editrice il Mulino.

Rawls, John (1972), A Theory of Justice, reprinted (1989), Oxford: Oxford University Press.

Reich, Robert B. (1991), The Work of Nations, Vintage Books.

Rocard, Michel (1996), Les moyens d'en sortir, Paris: Seuil.

Rodrigues, Maria João (1988, 1992), O Sistema de Emprego em Portugal, Lisbon: Publicações Dom Quixote.

Rodrigues, Maria João (1991, 1998), Competitividade e Recursos Humanos dilemas de Portugal na construção europeia, Lisbon: Publicações Dom Quixote.

Rodrigues, Maria João (coord.) (2000), Para uma Europa da Inovação e do Conhecimento - Emprego, Reformas Económicas e Coesão Social, Lisbon: Celta.

Romer, Paul (1990), 'Endogenous Technological change', Journal of Political Economy, 98, 71-102.

Ross, George (1995), Jacques Delors and European Integration, Cambridge: Polity Press.

Sen, Amartya (1999), Development as Freedom, New York: Anchor Books.

Shapiro, Carl and Hal R. Varian (1999), Information Rules - a Strategic Guide to the Network Economy, Boston, MA: Harvard Business School Press.

Silverberg, Gerald and Luc Soete (eds) (1994), The Economics of Growth and Technical Change - Technologies, Nations, Agents, Aldershot: Edward Elgar. 
Tapscott, Don (1995), The Digital Economy: Promise and Peril in the Age of Networked Intelligence, New York: McGraw-Hill.

Telò, Mario and Paul Magnette (1998), De Maastricht à Amsterdam-L'Europe et son nouveau Traité, Brussels: Editions Complexe.

Terestchenko, Michel (1994), Philosophie politique - 1. Individu et société, Paris: Hachette.

Thurow, Lester C. (1999), Building Wealth - The New Rules for Individuals, Companies, and Nations in a Knowledge-Based Economy, New York: HarperCollins.

Turner, Jonathan H. (1974), The Structure of Sociological Theory, reprinted (1991), Belmont: Wadsworth Publishing Company.

United Nations, Secretary-General (2000), We Peoples - United Nations 21st Century, New York: UN.

Van Der Heijden, Kees (1996), Scenarios: The Art of Strategic Conversation, Chichester: John Wiley.

Wallace, William (ed.) (1990), The dynamics of European integration, London: Pinter Publishers for the Royal Institute of International Affairs.

Walliser, Bernard and Charles Prou (1988), La Science Economique, Paris: Seuil.

Walliser, Bernard (1994), L'Intelligence de l'Economie, Paris: Editions Odile Jacob. 